\title{
Potency of Agriculture Commodity in Haruyan, Hulu Sungai Tengah Regency
}

\author{
Deasy Arisanty \\ Faculty of Teaching and Education \\ Universitas Lambung Mangkurat \\ Banjarmasin, Indonesia \\ Krisdiyanto \\ Faculty of Mathematics and Natural Sciences \\ Universitas Lambung Mangkurat \\ Banjarbaru, Indonesia \\ Salamiah \\ Faculty of Agriculture \\ Universitas Lambung Mangkurat \\ Banjarbaru, Indonesia
}

Faculty of Teaching and Education

Universitas Lambung Mangkurat

Banjarmasin, Indonesia

rosalinaunlam@gmail.com

\begin{abstract}
Hulu Sungai Tengah Regency, especially Haruyan has the potential to be developed as an agricultural area. Assessment of agricultural commodities is needed to determine the priorities of agriculture that will be developed in this region. The purpose of this study is to identify the potential of agricultural commodities in Haruyan, Hulu Sungai Tengah. The sample of the research was the land unit and village unit. The land unit is used to determine the land suitability for the commodity. Meanwhile, the village unit is used to collect the social economic data. Secondary data is collected from the government agency to determine the agriculture commodity. Location Quotient (LQ), shift share, and Focus Discussion Group (FGD) is used to analyze the agriculture commodity in Haruyan. The results showed that rice has S1 class (Very Suitable), corn has S2 class (Suitable), while commodity of onion, chili, and banana have an S3 class (Marginal Suitable). Based on LQ, corn and red pepper have base sector while the other sectors have non-base sector. The shift-share value is negative (-). The FGD results indicate that commodities to be developed by the community are rice, corn, and onion. This sector will be developed because it has the potential to be developed in Haruyan.
\end{abstract}

Keywords- commodity, agriculture, land suitability, location quotient, shift share

\section{INTRODUCTION}

The development of local excellent commodities is one of the efforts to compete in the national trade. The development of superior commodities has a comparative advantage both in terms of supply and demand. The development in terms of supply is characterized by the excellence in biophysical conditions, technology, and socio-economic conditions of farmers. It is in terms of the market demand for these commodities [1]. The development of superior commodities improves inter-regional competencies. It also improves the local economy in a region [2].

Leading commodities in the agricultural sector serve as the basis for determining the priority of agricultural crop development. Agricultural development can improve the yield and quality of agricultural production as well as increase income and living standards of a society [3].

Hulu Sungai Tengah Regency is one of the areas in South Kalimantan Province which also has potentials for the agricultural development. Spatial information data of location and extent of the less will result in less accurate planning, utilization, and development. This information will be used to select several land management alternatives to create stable and sustainable food security in Hulu Sungai Tengah related to the Government Regulation No. 68 of The Year 2002 on Food Security [4].

Hulu Sungai Tengah Regency is divided into 11 sub-district and 161 villages. The wetland area such as a river, swamp, and rice field has the area about 36140.17 hectares. The high potency of wetland will produce the high agricultural products. The purpose of this study is to identify the potential of agricultural commodities in Haruyan, Hulu Sungai Tengah.

\section{METHOD}

To identify the potential of land for agriculture, the land is suitable for the evaluation. The agriculture commodities consist of rice, corn, banana, orange, and chili. Land unit is used as the sampling area.

Location Quotients (LQ), analysis of shift share, and Focus Group Discussion (FGD) are used to identify the potential commodities to be developed. The secondary data is obtained from the government agency. The LQ technique is a simpler economic development tool with all its advantages and disadvantages. It is one of the most common approaches used in the basic economic model as a first step to understanding the sector of activity driving growth. It is the relative concentration or degree of specialization of economic activity through a comparative approach [5]. The LQ itself is a method based on the theory of economic basis to calculate the relative comparison of the value-added contribution of a sector in a region (districts/municipalities) to the added value of the 
relevant sectors in province/national or calculate the ratio of the share of $i$ sector output in the district to the share $i$ sector output in the province [6]. The LQ formula is as follows:

$$
L Q=\frac{{ }^{p D} P_{p t}}{P i_{p t}}
$$

LQ = Location Quotients

pi $=$ Production (harvested area) type of $i$ commodity at the sub-district level

$\mathrm{pt}=$ Production (harvested area) of all food crops at the subdistrict level

$\mathrm{Pi}=$ Production (harvested area) type of $i$ commodity at the district level

$\mathrm{Pt}=$ Production (harvested area) of commodity food crop at the district level

LQ> 1 indicates that there is a relative concentration in a region compared to the whole region. This means that $i$ commodity in a region is a base sector.

$\mathrm{LQ}=1$ is a non-base sector, meaning that $i$ commodity in a region has no comparative advantage. The production of the produced commodities is only sufficient to meet its own needs within the region.

LQ $<1$ is a non-base sector, meaning that $i$ commodity in one region does not have comparative advantage, $i$ commodity production in the region cannot fulfill own requirement and must get supply from outside region.

The Shift Share is one of the analytical tools to identify the economic source in terms of labor or income of a particular region. It is useful to estimate the development of the region against the wider region such as the development of subdistrict to the district, province, and national. It can see the development of sectors compared to the other sectors.

\section{RESULT AND DISCUSSION}

\section{A. Landform}

Landform is a certain appearance on every face of the earth that occurs due to the workmanship and the main process on the main layer of the earth's crust [7]. Both of these processes consist of endogenous and exogenous processes.

The landform in Hulu Sungai Tengah Regency based on the formation process is divided into three namely fluvial origins (F), denudational origin (D), and structural origin (S). The fluvial process $(\mathrm{F})$ is formed by the river activities. The denudational process (D) is formed by the degradation process such as landslides and erosion. Meanwhile, the structural process $(\mathrm{S})$ is formed by endogenous processes.

The form of fluvial origin in Hulu Sungai Tengah Regency is alluvial plain $(\mathrm{F} 1)$. It lies to the west of the Hulu Sungai Tengah region. Landform in Haruyan is denudational hills (D1), anticlinal hills (S1), and synclinal hills (S2).

\section{B. Slope}

The slope in Hulu Sungai Tengah is categorized into five classes: very flat, flat, moderate, steep, and very steep. The slope in Haruyan is the flat-moderate class $(8-25 \%)$.

\section{Soil}

The soil type in Hulu Sungai Tengah district is dominated by Red Yellow Podsolik soil type located in the hilly/mountainous area and organosol soil located on the flat area. The Red Yellow Podsolik soil is located in the eastern part, whereas the organosol soil is in the middle of the area. Haruyan has the organosol soil.

\section{Agricultural Commodity in Haruyan}

Haruyan is one of the sub-districts in Hulu Sungai Tengah. The total area of Haruyan is $148.63 \mathrm{~km}^{2}$. The land suitability of agriculture in Haruyan can be seen in Table 1.

TABLE 1. PRIORITY OF THE LAND SUITABILITY OF AGRICULTURAL FIELD OF HARUYAN SUB-DISTRICT, HULU SUNGAI TENGAH REGENCY

\begin{tabular}{|c|c|c|c|c|c|}
\hline \multirow[t]{2}{*}{ No. } & \multirow[t]{2}{*}{ Commodity } & \multicolumn{4}{|c|}{ The Land Suitability in Every Village } \\
\hline & & S1 (Very suitable) & S2 (Suitable) & S3 (Marginal Suitable) & $\begin{array}{c}\mathrm{N} \\
\text { (Not Suitable) }\end{array}$ \\
\hline 1 & Rice & $\begin{array}{c}\text { Haruyan, Haruyan Seberang, Tabat } \\
\text { Pandang, Lok Buntar, Pangambau } \\
\text { hilir Luar, Pangambau Hilir dalam, } \\
\text { Panggung, Pandanu, Barikin, Andang, } \\
\text { Teluk Mesjid, Mangunang Sebrang, } \\
\text { Mangunang, Hapulang, Pangambau } \\
\text { Hulu, Sungai Harang }\end{array}$ & & Batu Panggung & \\
\hline 2 & Corn & & $\begin{array}{c}\text { Pandanu, Pengambau Hilir Dalam, } \\
\text { Pengambau Hilir Luar, Haruyan, } \\
\text { Haruyan Sebrang, Sungai Harang, } \\
\text { Batu Panggung, Teluk Mejid, } \\
\text { Andang }\end{array}$ & $\begin{array}{l}\text { Hapulang, Pengambau Hulu, } \\
\text { Mangunang Seberang, Barikin, } \\
\text { Lokbuntar, Tabat Padang, } \\
\text { Mangunang }\end{array}$ & \\
\hline 3 & Chili & & & $\begin{array}{l}\text { Hapulang, Sungai Harang, Haruyan } \\
\text { Sebrang, Pengambau Hulu, } \\
\text { Mangunang Seberang, Andang, } \\
\text { Barikin, Haruyan, Lokbuntar, } \\
\text { Pandanu, Pengambau Hilir Dalam, } \\
\text { Pengambau Hilir Luar, Panggung, } \\
\text { Tabat Padang, Teluk Mesjid, } \\
\text { Mangunang, Batu Panggung, }\end{array}$ & \\
\hline
\end{tabular}


TABLE 1. cont.

\begin{tabular}{|c|c|c|c|}
\hline 4 & Onion & & $\begin{array}{l}\text { Hapulang, Sungai Harang, Haruyan } \\
\text { Sebrang, Pengambau Hulu, } \\
\text { Mangunang Seberang, Andang, } \\
\text { Barikin, Haruyan, Lokbuntar, } \\
\text { Pandanu, Pengambau Hilir Dalam, } \\
\text { Pengambau Hilir Luar, Panggung, } \\
\text { Tabat Padang, Teluk Mesjid, } \\
\text { Mangunang, Batu Panggung, }\end{array}$ \\
\hline 5 & Orange & & $\begin{array}{l}\text { Hapulang, Sungai Harang, Haruyan } \\
\text { Sebrang, Pengambau Hulu, } \\
\text { Mangunang Seberang, Andang, } \\
\text { Barikin, Haruyan, Lokbuntar, } \\
\text { Pandanu, Pengambau Hilir Dalam, } \\
\text { Pengambau Hilir Luar, Panggung, } \\
\text { Tabat Padang, Teluk Mesjid, } \\
\text { Mangunang, Batu Panggung, }\end{array}$ \\
\hline 6 & Banana & Sungai Harang & $\begin{array}{c}\text { Hapulang, Haruyan Sebrang, } \\
\text { Pengambau Hulu, Mangunang } \\
\text { Seberang, Andang, Barikin, } \\
\text { Haruyan, Lokbuntar, Pandanu, } \\
\text { Pengambau Hilir Dalam, } \\
\text { Pengambau Hilir Luar, Panggung, } \\
\text { Tabat Padang, Teluk Mesjid, } \\
\text { Mangunang, Batu Panggung, }\end{array}$ \\
\hline
\end{tabular}

Source: Primary Data Processing and Laboratory Results, 2016

The land suitability result is analyzed by the Soil Laboratory. The suitability for paddy is S1 (very suitable), corn is S2 (suitable), and the other commodity has S3 (marginal suitable).

The result of the land suitability supports the analysis result from LQ that banana, maize, chili, and orange as the base sector in some villages which have S2 suitability class for banana and corn, while S3 for chili and orange. The calculation of LQ is presented in Table 2.

TABLE 3. THE RESULT OF PRIORITY COMMODITY IN THE VILLAGES OF HARUYAN

\begin{tabular}{|c|c|c|c|c|}
\hline \multicolumn{5}{|c|}{ TABLE 3. THE RESULT OF PRIORITY COMMODITY IN THE VILLAGES OF HARUYAN } \\
\hline No & Commodity & Priority 1 & Priority 2 & Priority 3 \\
\hline 1 & Rice & Hapulang, Sungai Harang & Hapulang, & Hapulang, Sungi Harang, Haruyan Seberang, \\
\hline 2 & Corn & $\begin{array}{c}\text { Haruyan, Haruyan Seberang, Mangunang } \\
\text { Seberang, }\end{array}$ & $\begin{array}{c}\text { Sungai Harayan, Haruyan } \\
\text { Seberang }\end{array}$ & Sungai Harang, Haruyan, Haruyan Seberang \\
\hline 3 & Onion & Haruyan Seberang & $\begin{array}{c}\text { Haruyan Sungai Hirang, } \\
\text { Haruyan }\end{array}$ & Haruyan Seberang, Mangunang Seberang \\
\hline 4 & Chili & Haruyan & $\begin{array}{c}\text { Haruyan Seberang, Mangunang } \\
\text { Seberang }\end{array}$ & Haruyan \\
\hline 5 & Banana & & & \\
\hline 6 & Orange & & & \\
\hline
\end{tabular}

Source: Primary Data Processing, 2016

The potency and agriculture suitability of Haruyan data are obtained from the questionnaire and implementation of FGD at the Agriculture Department of Hulu Sungai Tengah Regency. There are six main commodities namely rice, corn, onion, chili, banana, and orange. The results of questionnaires showed that in priority 1 is rice, corn, onion, and chili in the village of Hapulang, Harang River, Haruyan, Haruyan Seberang, and Mangunang Seberang. In Priority 2 is rice, corn, onion, and chili in the village of Hapulang, Harang River, Haruyan, Haruyan Seberang, and Mangunang Seberang. Meanwhile, in Priority 3 is rice, corn, and onion in the villages of Hapulang, Harang River, Haruyan, Haruyan Seberang, and Mangunang Seberang. The rice is cultivated in the wet season, then corn will be cultivated in the dry season.
TABLE 2. CALCULATION RESULTS OF THE LQ AND SHIFT-SHARE

\begin{tabular}{|c|r|c|c|}
\hline Commodity & \multicolumn{2}{|c|}{ LQ } & Shiftshare \\
\hline Rice & - & Non Basis & - \\
\hline Corn & 32.26 & Basis & - \\
\hline Onion & - & Non Basis & - \\
\hline Chili & 27.95 & Basis & - \\
\hline Banana & 3.29 & Basis & - \\
\hline Orange & 5.86 & Basis & - \\
\hline
\end{tabular}

The FGDs are conducted to validate data obtained from land suitability and secondary data analysis results. They were carried out by agricultural service staff, village officials, and agricultural representatives. The final results of the commodities to be developed are listed in Table 4. The Priority commodity 1 is rice in Panggung village, which is a pilot village. The Priority 2 is corn, which Pandanu village is a pilot village. The Priority 3 is onion, where the pilot village is Panggung Village.

The development of agricultural commodities is not only think about the types of commodities to be developed but also think about the marketing of these commodities. In addition, the commodity processing should also be developed in order to have more values. The commodity 
processing can increase the value of commodities and increase farmer incomes [8].

TABLE 4. PRIORITY COMMODITY IN HARUYAN

\begin{tabular}{|l|l|l|l|}
\hline \multicolumn{1}{|c|}{ Commodity } & \multicolumn{1}{|c|}{ Rice } & \multicolumn{1}{c|}{ Orn } & \multicolumn{1}{c|}{ Onion } \\
\hline Village & Panggung & Pandanu & Panggung \\
\hline LQ & Non Base & Base & Non Base \\
\hline Shift-Share & - & - & - \\
\hline Land suitability & S1 & S2 & S3 \\
\hline
\end{tabular}

\section{CONCLUSION}

It can be concluded that rice has very suitability class (S1), corn has suitability class (S2), while the commodity of onion, chili, and banana have marginal suitability class (S3). Based on LQ value, corn and chili have the base sector, while the other sectors have non-base sector. The shift-share value is negative (-). The FGD results indicate that

\section{REFERENCES}

[1] R. Hendayana, "Aplikasi metode Location Quotient (LQ) dalam Penentuan Komoditas Unggulan Nasional" Informatika Pertanian Volume 12, 2003, pp 1-20.

[2] T. Wahyuningsih, H. Hehamahua, A.Kadir, Sahupala, "Determination of Agricultural Sector and Subsector Potentially Leading and with Superior in District Hie Location Quotient method Static, Dynamic Input and Output Location Quotient", Journal of Economics and Sustainable Development, Vol.5, No.28, 2014

[3] A. A. Luvianita, Analisis Komoditas Unggulan Pertanian Tanaman Pangan berdasarkan Metode Location Quotient di Kabupaten KaranganyarTahun 2014-2016, Fakultas Geografi, Surakarta: Universitas Muhammadiyah Surakarta, 2017

[4] Government Regulation no. 68 of 2002 on Food Security (Statute Book of 2002 No. 142 Supplement to Statute Book No. 4254), 2002.

[5] R. Hood, Economic Analysis: A Location Quotient, Primer, Principal Sun Region Associates, Inc, 1998 commodities to be developed by the community are rice, corn, and onion. This sector will be developed because it has the potential to be developed in Haruyan. The development of the agricultural sector in Haruyan should also be followed by the development of marketing so that the agricultural sector can increase the income of the people there.

[6] I. W. Rusastra, P. Simatupang dan B. Rachman, Pengembangan Ekonomi Pedesaan Berlandaskan Agribisnis, Pusat Penelitian dan Pengembangan Sosial Ekonomi Pertanian, 2000

[7] R. A. Van Zuidam, Geomorphologic Aerial Photographic Intrepretation and Mapping, International Institute for Aerial Survey and Earth Science, The Netherlands, 1983

[8] N. Kristiawan, A. R. Hanani, Soemarno, and S. Y. Tyasmoro, Leading "Product Development of Fruits Using Location Quotient InTuban Regency", IOSR Journal of Agriculture and Veterinary Science (IOSR-JAVS), Volume 9, Issue 8 Ver I, 2016, pp 81-84 